\title{
Strength and Durability Performance of Ferrocement Panels with the Influence of Corrosion Inhibitor
}

\author{
Saranya S, Kanniyappan S.P, Faizuneesa A, Dhilip Kumar R.G
}

\begin{abstract}
Success of Ferrocement, as with other construction material, depends largely upon its durability. ACI-549R strongly recommends that studies be undertaken to suggest durable and long-term anti-corrosion techniques to prevent penetration of water and salts that could lead to the corrosion of reinforcing wire mesh. The main objective of this study is to develop a durable Ferrocement panel by incorporating corrosion inhibitors as admixtures. The inhibitor used is sodium nitrate based inhibitor. Totally 24 Ferrocement panels are subjected to strength and durability study to ascertain the influence of inhibitor modification in cement mortar. Inhibitor admixed mortar offers marginally improved resistance against water absorption irrespective of tested dosage levels as compared to control mortar. There is a appreciable reduction in current development in the order of $18 \%$ for inhibitor admixed mortar as compared to control mortar, which is an indication of improved resistance against chloride penetration. Half-cell potential readings on galvanized Ferrocement panels should not be interpreted for corrosion probability as per ASTM C876. Ferrocement panels with crimped wire mesh and inhibitor modification offered low corrosion risk at the end of test period as per ASTM C876. There is an improvement in ultimate load carrying capacity for galvanized mesh Ferrocement panels of the order of 11-16\% upon inhibitor modification in mortar. Similar ultimate load carrying capacity for crimped wire mesh Ferrocement panels for control and inhibitor modified mortar. Ductile behavior associated with multiple crack formation before failure is observed for all tested panels. It can be concluded that crimped wire mesh panel Ferrocement panels offered appreciable stiffness, load carrying capacity and ductility as compared to galvanized mesh Ferrocement panel. Inhibitor incorporation appreciably improves the durable performance of Ferrocement panels.
\end{abstract}

Keywords: Ferrocement, Crimped wire mesh, Galvanized mesh, Half-cell potential, Stiffness.

\section{INTRODUCTION}

Ferro-cement is a building material with some similarities to reinforced concrete. Indeed, both materials have the same source. Ferro-cement is produced by applying cement mortar

Revised Manuscript Received on December 30, 2019.

* Correspondence Author

Saranya S, Civil Department, R.M.K. Engineering College, Kavaraipettai, Tamil nadu, India.

Kanniyappan S.P, Civil Department, R.M.K. Engineering College, Kavaraipettai, Tamil nadu, India.

Faizuneesa A, Civil Department, R.M.K. Engineering College, Kavaraipettai, Tamil nadu, India.

Dhilip Kumar R.G, Civil Department, R.M.K. Engineering College, Kavaraipettai, Tamil nadu, India.

(C) The Authors. Published by Blue Eyes Intelligence Engineering and Sciences Publication (BEIESP). This is an open access article under the CC BY-NC-ND license (http://creativecommons.org/licenses/by-nc-nd/4.0/) composed of fine aggregate and cement onto wire reinforcement using plasterer techniques. As a result the property of Ferrocement distinguishes it from reinforced concrete. While of similar durability, it is more elastic than reinforced concrete. Ferrocement is a highly versatile form of reinforced concrete, the matrix used in Ferrocement primarily consists of mortar made with Portland cement, water, and aggregate. A mineral admixture may be blended with the cement for special applications. Normally, the aggregate consists of well-graded fine aggregate (sand) that passes on ASTM No. 8 (2.36 mm) sieve. If permitted by the size of the mesh openings and the distance between layers of mesh, small-size coarse aggregate may be added to the sand.

\section{A. Cement}

The cement should be fresh, of uniform consistency, and free of lumps and foreign matter. It should be stored under dry conditions for a short duration as possible. The choice of particular cement should depend on the service conditions. Service conditions can be classified as electrochemically passive or active.

\section{B. Aggregates}

Normal-weight fine aggregate (sand) is the most common aggregate used in Ferrocement. It should comply with ASTM C 33-86 requirements (for fine aggregate) or an equivalent standard. It should be clean, inert, free of organic matter and deleterious substances, and relatively free of silt and clay. Hard, strong, and sharp silica aggregates achieve the best strength results.

\section{Water}

The mixing water should be fresh, clean, and potable. The water should be relatively free from organic matter, silt, oil, sugar, chloride, and acidic material. It should have a $\mathrm{pH} \sim 7$ to minimize the reduction in the $\mathrm{pH}$ of the mortar slurry. Salt water is not acceptable, but chlorinated drinking water can be used.

\section{Reinforcement}

The reinforcement should be clean and free from deleterious materials such as dust, loose rust, coating of paint, oil, or similar substances. Wire mesh with closely spaced wires is the most commonly used reinforcement in Ferrocement. Expanded metal, welded-wire fabric, wires or rods, prestressing tendons, and discontinuous fibers are also being used in special applications or for reasons of performance or economy. 


\section{E. Wire Mesh}

Common wire meshes have hexagonal or square openings. Meshes with hexagonal openings are sometimes referred to as chicken wire mesh or aviary mesh. They are not structurally as efficient as meshes with square openings because the wires are not always oriented in the directions of the principal (maximum) stresses. However, they are very flexible and can be used in doubly curved elements. Meshes with square openings are available in welded or woven form.

\section{BASIC MATERIAL PROPERTIES AND MORTAR MIX}

The basic properties of 53 grade ordinary Portland cement such as consistency, initial setting time, final setting time and specific gravity are tabulated in Table 1 as per IS 4031-1998. The properties of fine aggregate are tabulated in Table 2 as per IS 383-1970.

Table-I: Properties of $\mathbf{5 3}$ grade ordinary Portland cement

\begin{tabular}{|l|c|}
\hline \multicolumn{1}{|c|}{ Test details } & Obtained value \\
\hline Consistency & $27 \%$ \\
\hline Initial Setting Time & $72 \mathrm{~min}$ \\
\hline Final Setting Time & $330 \mathrm{~min}$ \\
\hline Specific Gravity & 3.1 \\
\hline
\end{tabular}

Table-II: Properties of Fine Aggregate

\begin{tabular}{|l|c|}
\hline \multicolumn{1}{|c|}{ Test details } & Obtained value \\
\hline Water Absorption & $2 \%$ \\
\hline Specific Gravity & 2.63 \\
\hline Fineness Modulus & 3.05 \\
\hline
\end{tabular}

\section{A. Galvanized Wire Mesh}

Galvanized wire mesh is an electric fusion welded prefabricated joined grid consisting of a series of parallel longitudinal wires with accurate spacing welded to cross wires at the required spacing. The welded wire mesh is a metal wire screen that is made up of low carbon steel wire or stainless steel wire. It is available in various sizes and shapes. Galvanized wire mesh used in this study is $1 \mathrm{~mm}$ diameter and $12.5 \mathrm{~mm}$ square mesh.

\section{B. Crimped Wire Mesh}

Crimped Wire Mesh can be also known as the iron crimped mesh, stainless steel crimped mesh, black iron crimped mesh according to different materials. Crimped Wire Mesh is made in a variety of materials through crimping mesh machine, a kind of universal wire products with square or rectangular openings. Crimped wire mesh used in this study is $2 \mathrm{~mm}$ diameter and $10 \mathrm{~mm}$ square mesh.

\section{Corrosion Inhibitor}

\begin{tabular}{|c|c|}
\hline Name & Sodium \\
\hline Density & : $1.152 \mathrm{Kg} / \mathrm{m}^{3}$ \\
\hline $\mathrm{pH}$ & : 11.55 \\
\hline
\end{tabular}

Colour : Brown

Workability : Free Flowing Liquid

\section{COMPRESSIVE STRENGTH TEST}

Compressive strength test was conducted as per IS 516 1968, to find the effect of inhibitor on the compressive strength behavior of cement mortar. The size of the specimen is 100 mm cube. After $24 \mathrm{hr}$, the cubes are demoulded and subjected to water curing. Compression testing machine of $3000 \mathrm{kN}$ capacity was used for the test. The maximum load at which specimen failed was recorded. Table-III reveals the details of water cement ratio and corrosion inhibitor involved in this study. Table-IV reveals the Observation on Compressive strength test for control and inhibitor admixed concrete.

Table-III: Details of water cement ratio and corrosion inhibitor

\begin{tabular}{|c|c|l|}
\hline Sl. No & Water Cement Ratio & \multicolumn{1}{c|}{ Description } \\
\hline 1. & 0.425 & Control Concrete \\
\hline 2. & 0.425 & Inhibited concrete (1\%) \\
\hline 3. & 0.40 & Inhibited concrete (2\%) \\
\hline
\end{tabular}

Table-IV: Observation on Compressive strength test for control and inhibitor admixed concrete

\begin{tabular}{|c|c|c|c|c|}
\hline \multirow{2}{*}{ Sl. No } & \multirow{2}{*}{$\begin{array}{l}\text { Specimen } \\
\text { Type }\end{array}$} & \multirow{2}{*}{$\begin{array}{c}\text { Water- } \\
\text { Cement ratio }\end{array}$} & \multicolumn{2}{|c|}{$\begin{array}{c}\text { Compression } \\
\text { Strength } \\
\left(\mathrm{N} / \mathbf{m m}^{2}\right) \\
\end{array}$} \\
\hline & & & $\begin{array}{c}7^{\text {th }} \\
\text { Day }\end{array}$ & $\begin{array}{l}28^{\text {th }} \\
\text { Day }\end{array}$ \\
\hline 1. & $\mathrm{CC}$ & 0.425 & 24 & 35 \\
\hline 2. & 1\% Inhibitor & 0.425 & 31 & 38 \\
\hline 3. & $2 \%$ Inhibitor & 0.4 & 33 & 41 \\
\hline
\end{tabular}

"Fig.1" shows the comparison of compressive strength for control and inhibitor admixed mortar. It can be seen that there is an increase in compressive strength in all the dosages, with the addition of inhibitor compared to the control concrete in both $7^{\text {th }}$ and $28^{\text {th }}$ day compressive strength.

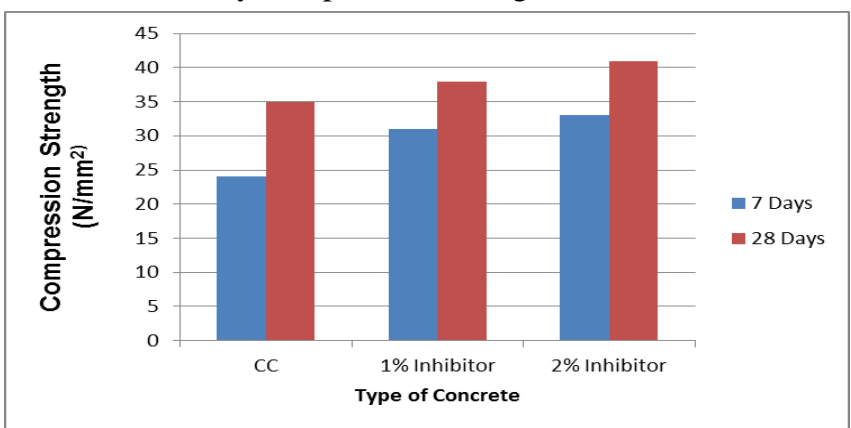

Fig. 1.Observations on compressive strength for Control concrete and inhibitor admixed concrete.

Compressive strength $=\mathrm{P} / \mathrm{A}$

Where, $\mathrm{P}=$ Maximum load in Newton,

$\mathrm{A}=$ cross - sectional area of the specimen in $\mathrm{mm}^{2}$

In $7^{\text {th }}$ day observation there is a gradual increase in the strength in the order of $29.17 \%$ with respective to the addition of $1 \%$ inhibitor, compared to the control concrete. When $2 \%$ inhibitor is added and the water cement ratio is reduced to 0.40 there was a marginal increase in the strength in the order of $37.5 \%$. Thus it can be concluded that the addition of inhibitor has increased the compressive strength significantly in all the dosages of inhibitor.

\section{EXPERIMENTAL INVESTIGATION}

The performance evaluation tests for inhibited cement mortar were carried out with the following experiments. Various dosages of inhibitor were used corresponding to the decrement in the water cement ratio.

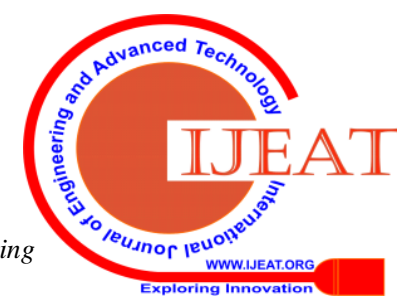




\section{DURABILITY TESTS:}

- Water Absorption Test

- Rapid Chloride Penetration Test.

- Half-Cell Potential Test.

These tests are to be conducted as per Indian and ASTM standards.

\section{STRENGTH TEST:}

- Flexural Strength Test.

\section{A. Water Absorption Test}

The water absorption of concrete is determined as per ASTM C642. Totally 9 mortar cube specimens of $100 \mathrm{~mm}$ size were subjected to water absorption test. This test is done after 28 days curing and subsequently dried in atmosphere for 24 hours. The specimens are kept inside the oven for not less than 24 hours at a temperature of $100^{\circ} \mathrm{C}-110^{\circ} \mathrm{C}$. After that the specimen is removed from the oven, allowed to cool in dry air to a room temperature $25^{\circ} \mathrm{C}$. The dry weight of each specimen is taken. Then the specimen is immersed in to water and weight of each specimen is taken at time interval of 10 minutes for first 2 hours, after that every half an hour up to 4 hour, thereafter, at every hour up to 24 hours and tabulated.

\section{B. Rapid Chloride Penetration Test}

This test method is assessed to find out the penetration depth of chloride ingressed to the mortar surface, as per ASTM - C -1202. The process is achieved by monitoring the amount of electrical current passed through $50 \mathrm{~mm}$ thick slices of $100 \mathrm{~mm}$ nominal diameter cores during 6 hours period. Totally 9 mortar cylinders of size $100 \mathrm{~mm}$ x $200 \mathrm{~mm}$ were cast and $50 \mathrm{~mm}$ slices was cut with a help of concrete angle cutter. Totally three different combinations were cast and three cylinders were cast in each category. Rapid Chloride Penetration test procedure is given as follows:

- The sliced specimen of $100 \mathrm{~mm}$ diameter and $50 \mathrm{~mm}$ thick is placed between the two acrylic plastic cells.

- The exposed face of specimen is covered with an impermeable material such as rubber or plastic sheeting. Rubber stopper or cork is placed in cell filling hole to restrict moisture movement.

- A $100 \mathrm{~mm}$ outside diameter by $75 \mathrm{~mm}$ inside diameter is placed by $6 \mathrm{~mm}$ thick circular vulcanized rubber gasket in each half of the test cell. The specimen is inserted and clamped with the two halves of the test cell together to seal.

- The ends of the specimen are sealed with silicon sealant for further protection to prevent the leakage of solution.

- The side of the cell containing the top surface of the specimen is filled with $3.0 \% \mathrm{NaCl}$ solution. (That side of the cell will be connected to the negative terminal of the power supply)

- The other side of the cell (which will be connected to the positive terminal of the power supply) is filled with $0.3 \mathrm{~N}$ $\mathrm{NaOH}$ solution.

- Lead wires are attached to cell banana posts. Electrical connections are made to voltage with the cell corresponding to the positive and negative terminals.

- Power supply is turned on, set to $60 \mathrm{~V}$ and initial current reading is recorded.

- Readings are recorded for every 30 minutes until the test gets completed. "Fig.2" shows the Rapid Chloride Penetration test in progress.

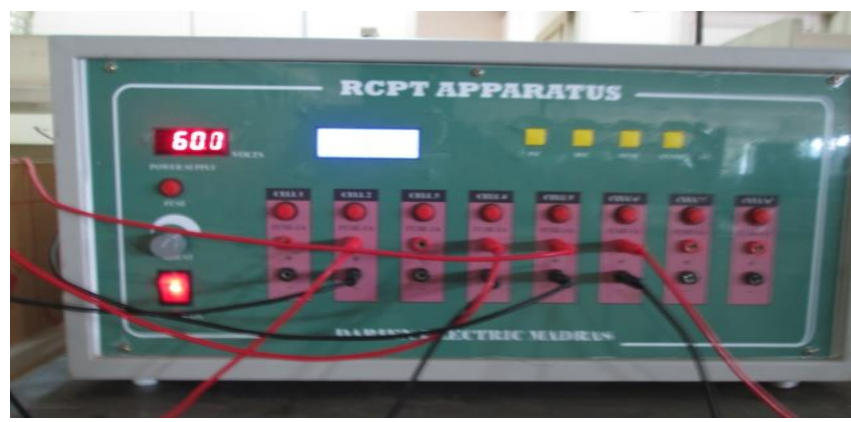

Fig. 2.Rapid Chloride Penetration test in progress

Table-V: RCPT Ratings (as per ASTM C1202)

\begin{tabular}{|c|c|}
\hline Charge Passed (Coulombs) & Chloride Ion Penetrability \\
\hline$>4000$ & High \\
\hline $2000-4000$ & Moderate \\
\hline $1000-2000$ & Low \\
\hline $100-1000$ & Very Low \\
\hline$<100$ & Negligible \\
\hline
\end{tabular}

\section{Half-Cell Potential Test}

ASTM C876 - 91 gives a Standard Test Method for Half-Cell Potential. Corrosion of reinforcing steel is an electro-chemical process and the behavior of the steel can be characterized by measuring its half-cell potential. Greater the potential, higher the risk that corrosion is taking place. An electrode forms one half of the cell and the steel wire mesh in the cement mortar forms another half-cell. The preferred reference electrode for site use is silver/silver chloride in potassium chloride solution although the copper/copper sulphate electrode is still widely used. The test procedure is given as follows:

- The Ferrocement panel of size 900 x 300 x 25 mm was cast by soldering the wire with wire mesh in order to conduct the Half-cell potential test. M-seal is used to protect the soldering to avoid disconnection.

- Grid lines are marked to measure the different voltage potential at various locations of the panel.

- Grid lines are marked by leaving $30 \mathrm{~mm}$ clear space on all the sides and the remaining $840 \mathrm{~mm}$ is divided equally to measure the potential difference.

- The Ferrocement panels are subjected to alternate wetting and drying cycle. One cycle consists of four days, two days wetting and two days drying.

- After each wetting process, potential reading of the wire mesh is monitored with respect to Saturated Calomel Electrode (SCE) and compared with the ASTM criteria outline in ASTM C876-1999 for the probability of corrosion. "Fig. 3" shows the Half-cell potential in progress.

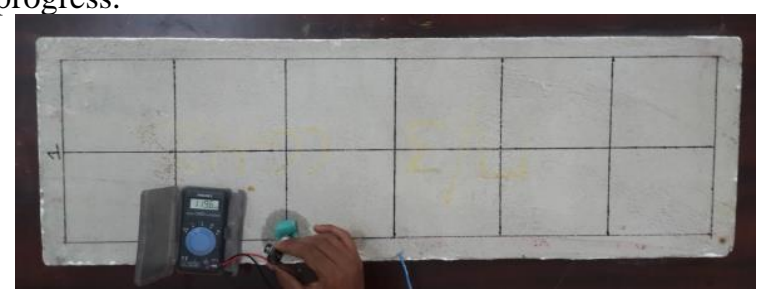

Fig.3 Half-Cell Potential test in progress 
D. Flexural Strength Test influence of inhibitor addition on the flexural strength of Ferrocement panel. The size of the panel is $900 \mathrm{x} 300 \mathrm{x}$ $25 \mathrm{~mm}$. The test was carried out under Universal Testing Machine of 40 Tons capacity with addition fixtures to conduct flexure test. The experiment was conducted with Ferrocement panel using 1:2 mix with varying W/C ratios of 0.425 with control concrete, 0.45 with $1 \%$ inhibitor, and 0.40 with $2 \%$ inhibitor. Totally 18 specimens were cast to obtain 28 days flexural strength of the concrete and 12 panels which are subjected to half-cell potential test are also tested for flexure test. The ferrocement slab panels were casted with embedded wire mesh in cement mortar. Thickness of the panel is $25 \mathrm{~mm}$ in which the cement mortar is placed up to the mid height of the panel (i.e) $12 \mathrm{~mm}$ approximately and then wire mesh is placed over it. Wire mesh is placed in such a way that equal cover of $10 \mathrm{~mm}$ is provided on all the sides and after that cement mortar is applied and finished smoothly "Fig.4" and "Fig.5" shows the casting of test specimen.

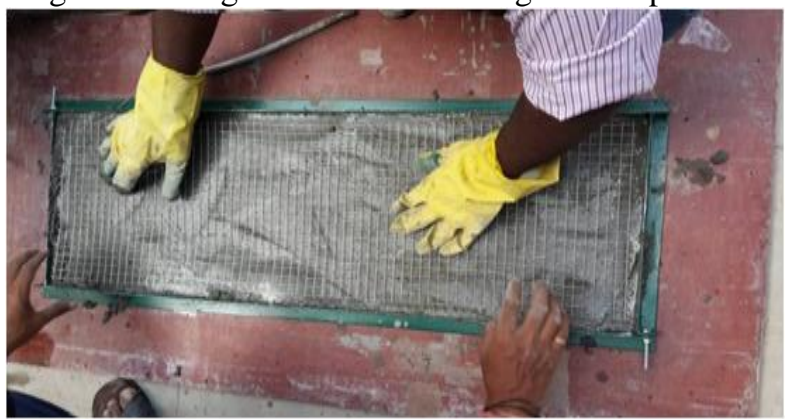

Fig.4 placing of wire mesh during casting

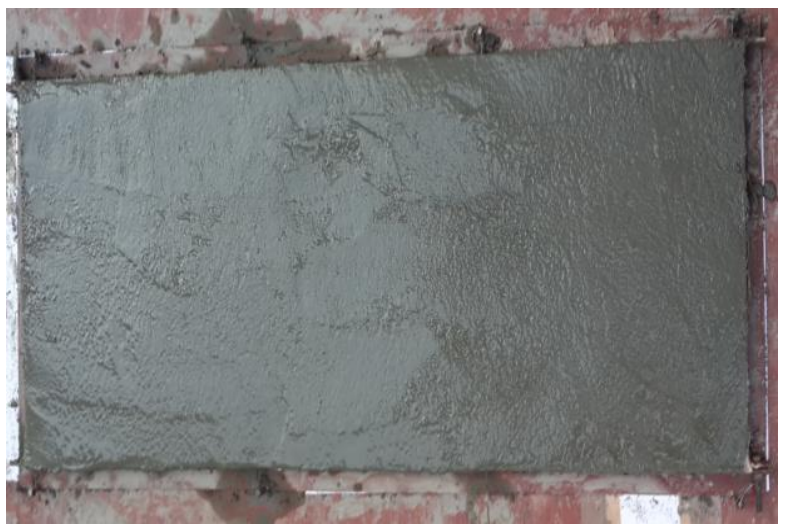

Fig.5 Ferrocement panel after finishing

The load-deflection behavior of Ferrocement roof panels was obtained by placing the slab panel in the specially made seating assembly as shown in the figures. The support assembly is specially made to provide simply support span for the Ferrocement panel of effective span $750 \mathrm{~mm}$. spreader beam is used to test it as a four point loading flexural test of $250 \mathrm{~mm}$ centre to centre point of load. To measure the deflection, dial gauge is kept at the tension face and at the centre of the panel in order to find out the maximum deflection. The load was applied very slowly (i.e) $8 \mathrm{~kg}$ interval in order to find out the exact behavior of the panel and also to locate and note down the first crack precisely. The test specimen is white washed in order to locate the crack and crack pattern precisely. The load was applied until the specimen fails
This test was carried out as per IS 516-1968 to access the

and the ultimate load was recorded. The ultimate load and the deflection are tabulated to compare with different type of mortar mixes. The load deflection behaviors of all the specimens are represented in graph in order to see the flexural behavior. "Fig.6" shows the four point loading flexural test set up and "Fig.7" shows the flexural test in progress.

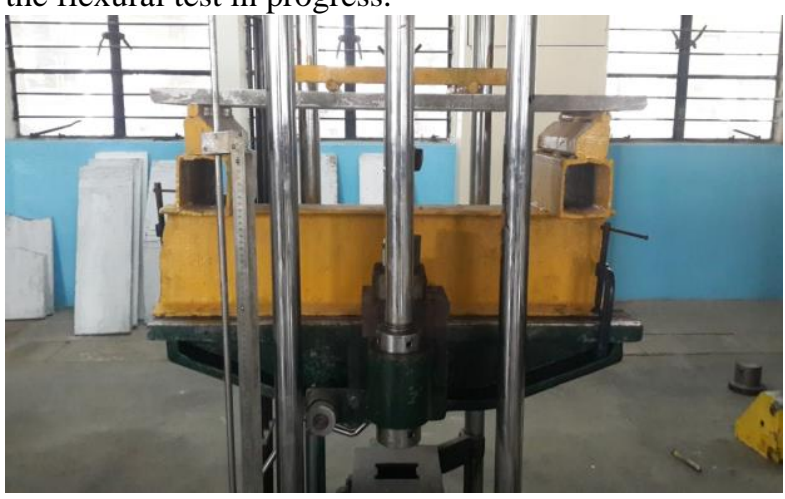

Fig.6 Flexural Strength Test Set up

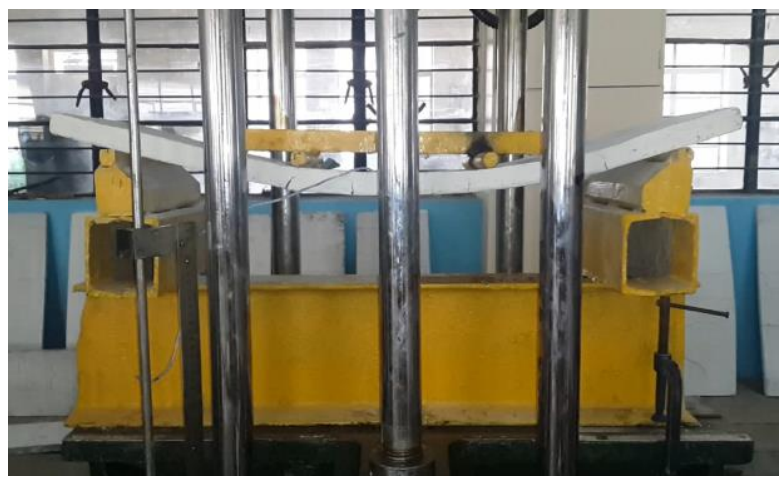

Fig.7 Flexural Strength Test in progress

\section{RESULTS AND DISCUSSION}

\section{A. Water Absorption Test}

Table VI shows the observation on water absorption test in terms of percentage change in mass.

"Fig.8" shows Cumulative water absorption at the end of different period of exposure. Water absorption of control cement mortar is high when compared to the $1 \%$ and $2 \%$

inhibited cement mortar. Therefore the inhibited cement mortar is more reliable in order to prevent water entering in to the specimen thereby reducing the probability of corrosion.

Table-VI: Water absorption Test Results

\begin{tabular}{|c|c|c|c|c|}
\hline \multirow{2}{*}{$\begin{array}{l}\text { Sl. } \\
\text { No }\end{array}$} & \multirow{2}{*}{$\begin{array}{l}\text { Avg. water } \\
\text { absorption } \\
\text { (minutes) }\end{array}$} & \multicolumn{3}{|c|}{ Specimen Type } \\
\hline & & CC & $1 \%$ Inhibitor & 2\% Inhibitor \\
\hline 1. & 10 & 2.28 & 2.27 & 2.27 \\
\hline 2. & 20 & 2.31 & 2.30 & 2.29 \\
\hline 3. & 30 & 2.33 & 2.31 & 2.30 \\
\hline
\end{tabular}




\begin{tabular}{|c|c|c|c|c|}
\hline 4. & 40 & 2.33 & 2.31 & 2.31 \\
\hline 5. & 50 & 2.34 & 2.31 & 2.31 \\
\hline 6. & 60 & 2.35 & 2.32 & 2.31 \\
\hline 7. & 90 & 2.35 & 2.32 & 2.31 \\
\hline 8. & 120 & 2.35 & 2.32 & 2.31 \\
\hline 9. & 150 & 2.35 & 2.32 & 2.32 \\
\hline 10. & 180 & 2.35 & 2.32 & 2.32 \\
\hline 11. & 1440 & 2.36 & 2.32 & 2.32 \\
\hline
\end{tabular}

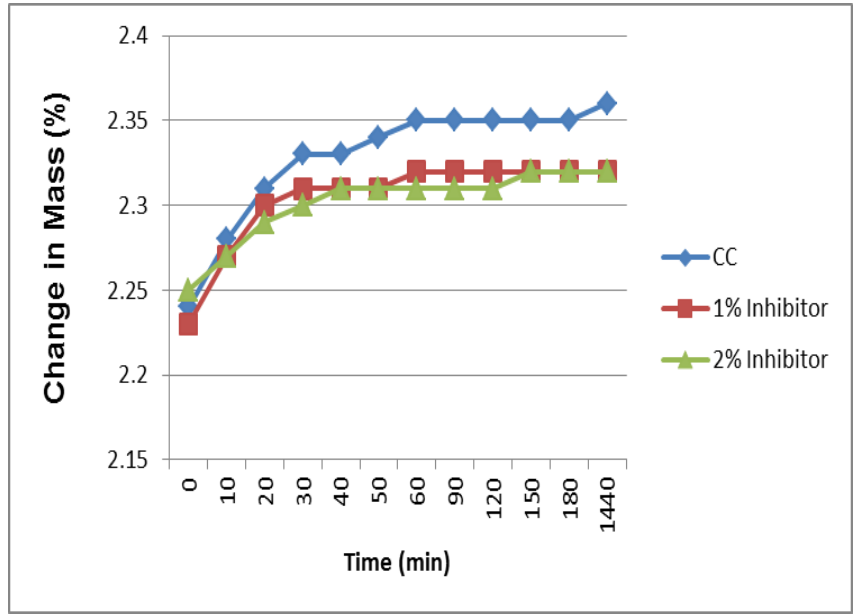

Fig.8 Cumulative Water Absorption Test Results

\section{B. Rapid Chloride Penetration Test}

In this test, a potential difference of $60 \mathrm{~V}$ DC is maintained across the ends of the specimen, one of which is immersed in a sodium chloride solution, the other in a sodium hydroxide solution. The total charge passed, in coulombs, has been found to be related to the resistance of the specimen to chloride ion penetration. "Fig.9" shows the chloride penetration for control and inhibitor admixed. It is observed that inhibitor admixed mortar offers more resistance to chloride than compared to control specimen.

In control specimen till 120 minutes there is a marginal increase in the passage of current and after that the resistance to chloride fails resulting in the steep increase in the conductivity of current and ending up in $262 \mathrm{~mA}$ current passage. In the addition of $1 \%$ and $2 \%$ inhibitor there is a gradual increase in the current and ends in 191mA, $195 \mathrm{~mA}$.

The addition of $1 \%$ inhibitor has offered more resistance to chloride compared to the control concrete. "Fig 10" shows the passage of current corresponding to dosage of inhibitor. With the addition of $1 \%$ and $2 \%$ inhibitor there is a drastic decrease in the current flow of the order $33.3 \%$ and the inhibited mortar has offered more resistance to chloride compared to the control specimen. It is observed that the penetration of chloride is Normal for inhibited cement mortar and control specimen depends on passage of current in mortar but the current flow through the control specimen is on the verge to the risk level in compare to inhibited cement mortar. Upon the increase of inhibitor dosage of $2 \%$ there is a gradual decrease in the current flow of the order of $47.1 \%$.Thus it is concluded that the addition of inhibitor has reduced the flow of current thus resisting the concrete to chloride.

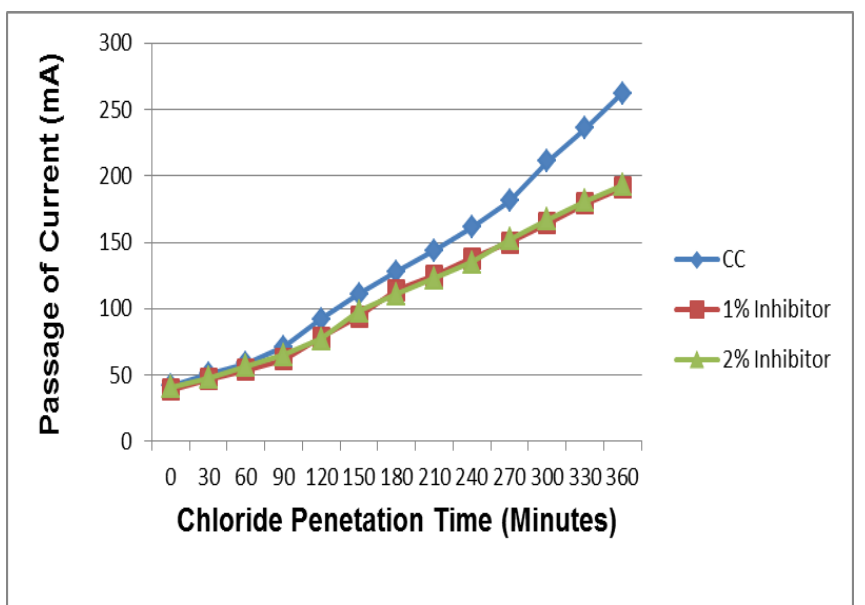

Fig.9 Observations on passage of current corresponding to the time duration

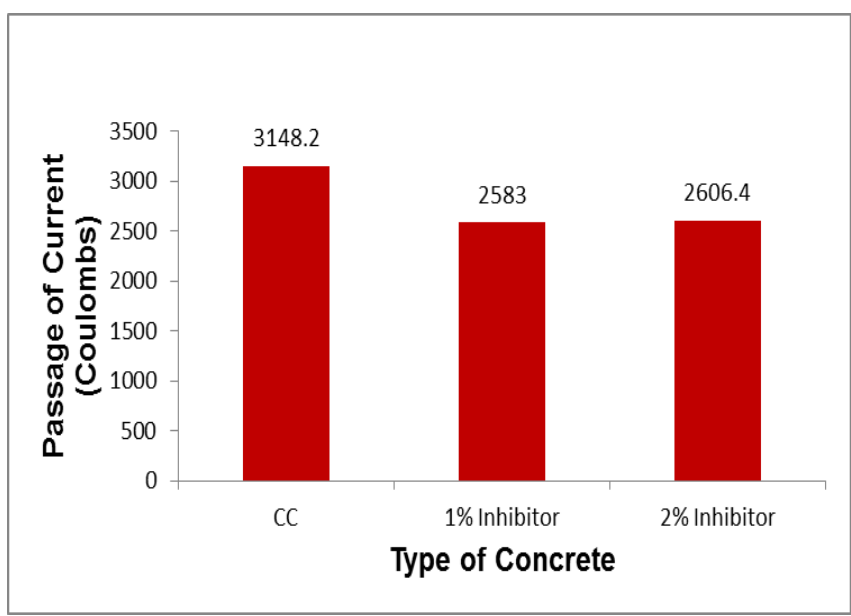

Fig.10 Observations on passage of current corresponding to Type of concrete

\section{Half-Cell Potential Test}

Corrosion potential measurement is the simplest way of assessing the severity of corrosion of steel wire mesh inside the cement mortar. An increase in chloride ion concentration causes significant corrosion of steel. The chloride induced corrosion is associated with a significant increase in negative potential values. This prediction coincides with the ASTM C876 interpretation for corrosion of steel in cement mortar. The ferrocement panel is subjected to alternate wetting and dry cycle. Cycle consists of 4 days, 2 days wetting process is carried out by immersing the panel in the $3 \% \mathrm{NaCl}$ solution completely. Drying cycle is carried out by keeping it at the atmospheric condition for 2 days. The difference in voltage potential is measured at the end of each wetting cycle. Table-VII shows the probability of corrosion of steel in cement mortar as per ASTM C 876-1999.

Table-VII: Probability for Corrosion of Steel in Cement mortar as per ASTM C 876-1999.

\begin{tabular}{|c|c|c|c|}
\hline $\begin{array}{c}\text { Sl. } \\
\text { No }\end{array}$ & $\begin{array}{c}\text { Potential, mV } \\
\text { versus SCE }\end{array}$ & $\begin{array}{c}\text { Potential, mV versus } \\
\text { copper/copper } \\
\text { sulphate }\end{array}$ & $\begin{array}{c}\text { Probability } \\
\text { of corrosion (\%) }\end{array}$ \\
\hline 1 & $>-126 \mathrm{mV}$ & $>-200 \mathrm{mV}$ & Low corrosion risk $(<10 \%)$ \\
\hline
\end{tabular}




\begin{tabular}{|c|c|c|c|}
\hline 2 & $\begin{array}{c}-126 \mathrm{mV} \text { to }- \\
276 \mathrm{mV}\end{array}$ & $-200 \mathrm{mV}$ to $-350 \mathrm{mV}$ & Intermediate corrosion risk \\
\hline 3 & $>-276 \mathrm{mV}$ & $>-350 \mathrm{mV}$ & $\begin{array}{c}\text { High }(<90 \% \text { risk of } \\
\text { corrosion })\end{array}$ \\
\hline 4 & $>-426 \mathrm{mV}$ & $>-500 \mathrm{mV}$ & Severe corrosion \\
\hline
\end{tabular}

"Fig.11" shows the passage of current measured close to the cover distance. It is clearly evident that probability of corrosion in the control specimen is higher $(-348 \mathrm{mV})$ when compared to $1 \%$ inhibited cement mortar $(-102 \mathrm{mv})$ as well as $2 \%$ inhibited cement mortar $(-105 \mathrm{mV})$.

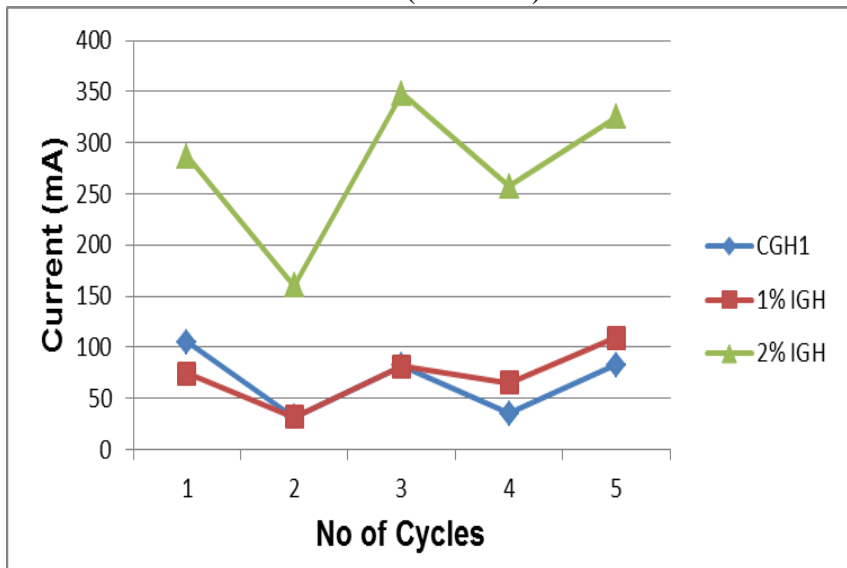

Fig.11 Observations on passage of current corresponding to no of cycles close to the cover distance

"Fig.12" shows the passage of current corresponding to number of cycles measured at the center of the panel. It can be seen that the probability of corrosion in the control specimen is higher $(-302 \mathrm{mV})$ when compared to $1 \%$ inhibited cement mortar $(-103 \mathrm{mV})$ as well as $2 \%$ inhibited cement mortar $(-98 \mathrm{mV})$.

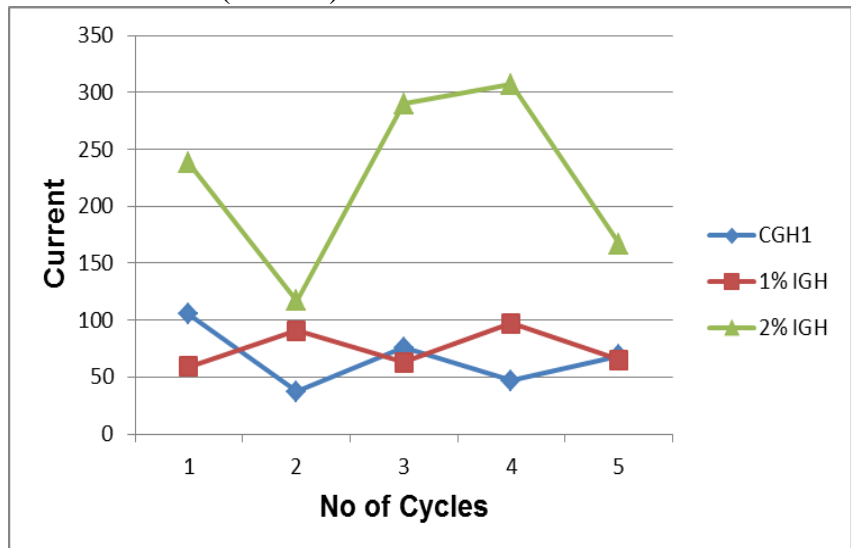

Fig.12 Observations on passage of current corresponding to number of cycles at the center

"Fig.13" shows the passage of current corresponding to no of cycles measured very close to the cover distance. It is clearly evident that the probability of corrosion in the control specimen is higher $(-448 \mathrm{mV})$ when compared to the $1 \%$ inhibited cement mortar $(-229 \mathrm{mV})$ and $2 \%$ inhibited cement mortar $(-198 \mathrm{mV})$.

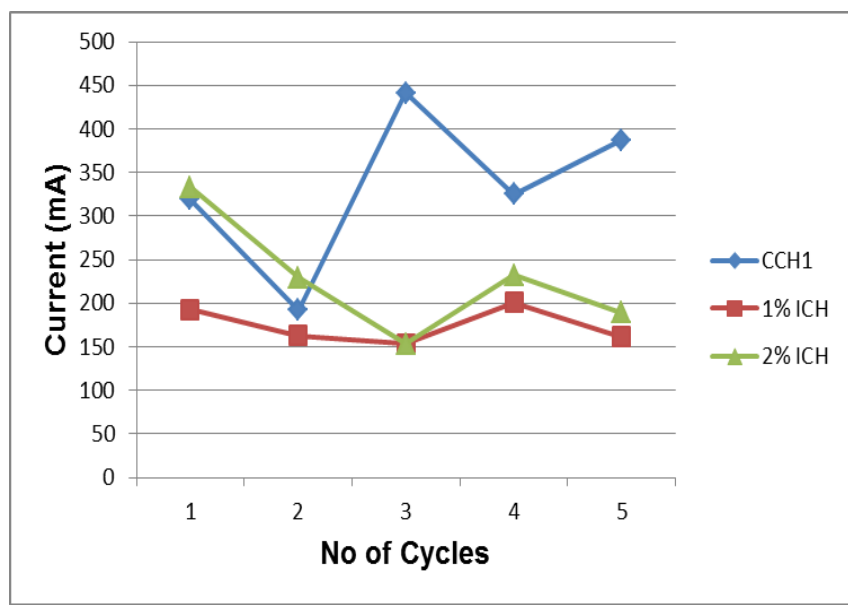

Fig.13 Observations on passage of current corresponding to no of cycles close to the cover distance

"Fig.14" shows the passage of current measured at the center of the panel. It can be seen that the probability of corrosion in the control specimen is higher $(-441 \mathrm{mV})$ when compared to $1 \%$ inhibited cement mortar $(-184 \mathrm{mV})$ as well as 2\%inhibited cement mortar $(-236 \mathrm{mV})$.

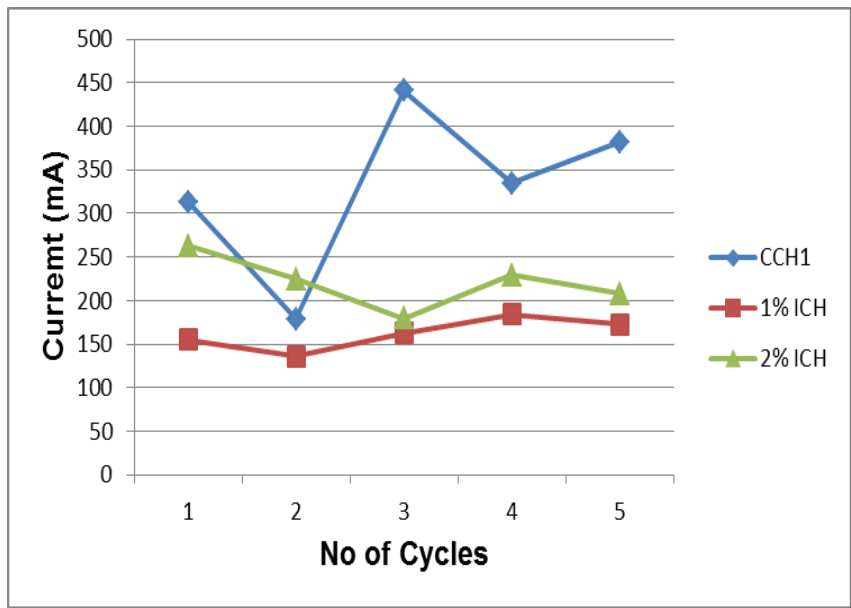

Fig.14 Observations on passage of current corresponding to no of cycles at the center

\section{Flexural Strength Test}

Flexural strength behavior of 24 Ferrocement roof slab panels made from crimped wire mesh; galvanized wire mesh, were obtained and analyzed. The evaluation criteria include mesh types, ultimate load, crack type and maximum deflection. Table-VIII shows the ultimate load and maximum deflection of the galvanized single layer Ferrocement panels.

It is clearly evident that by incorporating corrosion inhibitor in to the matrix increases the load carrying capacity of the panel as well as maximum deflection. The ultimate load in comparison with inhibited cement mortar and the control cement mortar, the $2 \%$ inhibited panel shows greater ultimate load (744kg) were as $1 \%$ inhibited panel and control panel shows less ultimate load as $712 \mathrm{~kg}$ and $640 \mathrm{~kg}$ respectively. "Fig. 15" shows the load deflection behavior.

Table-VIII: Observation of ultimate load and deflection

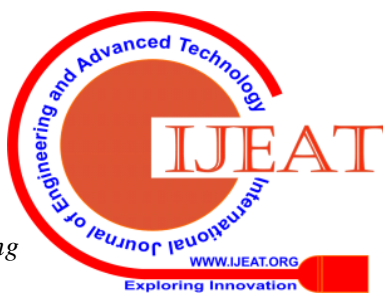




\begin{tabular}{|c|c|c|c|c|}
\hline Sl. No & $\begin{array}{c}\text { Specimen } \\
\text { Type }\end{array}$ & Description & $\begin{array}{c}\text { Ultimate } \\
\text { Load } \\
\mathbf{( K g )}\end{array}$ & $\begin{array}{c}\text { Maximum } \\
\text { deflection (mm) }\end{array}$ \\
\hline 1. & CG & $\begin{array}{c}\text { Control } \\
\text { Galvanized } \\
\text { Single Layer }\end{array}$ & 640 & 12 \\
\hline 2. & $1 \% \mathrm{IG}$ & $\begin{array}{c}1 \% \text { Inhibited } \\
\text { Galvanized } \\
\text { Single Layer }\end{array}$ & 712 & 12 \\
\hline 3. & $2 \% \mathrm{IG}$ & $\begin{array}{c}2 \% \text { Inhibited } \\
\text { Galvanized } \\
\text { Single Layer }\end{array}$ & 744 & 14 \\
\hline
\end{tabular}

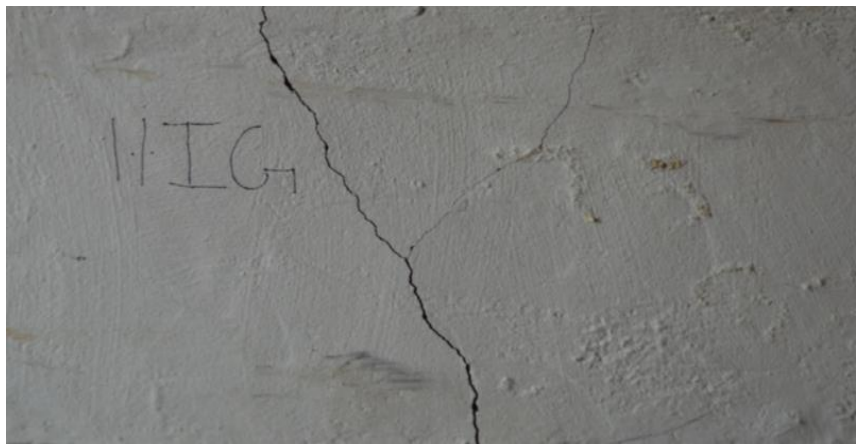

Fig. 17 crack pattern of $1 \%$ inhibited single layer galvanized panel
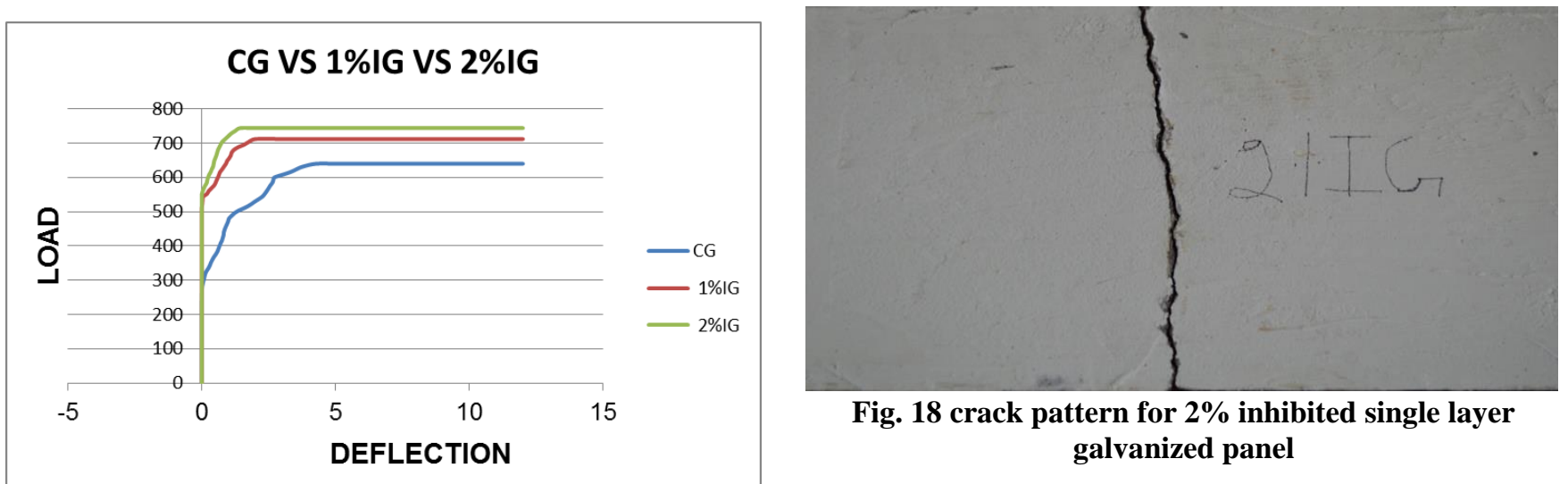

Fig. 18 crack pattern for $2 \%$ inhibited single layer galvanized panel

Fig.15 Load Deflection behavior of galvanized single layer galvanized Ferrocement panel

It can be seen that 2\% inhibited Ferrocement panel offers appreciable deflection upon increasing the load. The max deflection occurs in the $2 \%$ inhibited Ferrocement panel before failure which shows that the $2 \%$ inhibited panel is more ductile than the other two panels. It can be concluded that addition of corrosion inhibitor does not affect the flexural behavior instead it increases the ultimate load carrying capacity and offers maximum deflection before failure. "Fig.16", "Fig.17", "Fig.18" shows the crack pattern of the galvanized wire mesh panels with different percentage of corrosion inhibitor. It is clearly evident that galvanized wire mesh panel cracks at the center and width of the crack increases and it collapses.

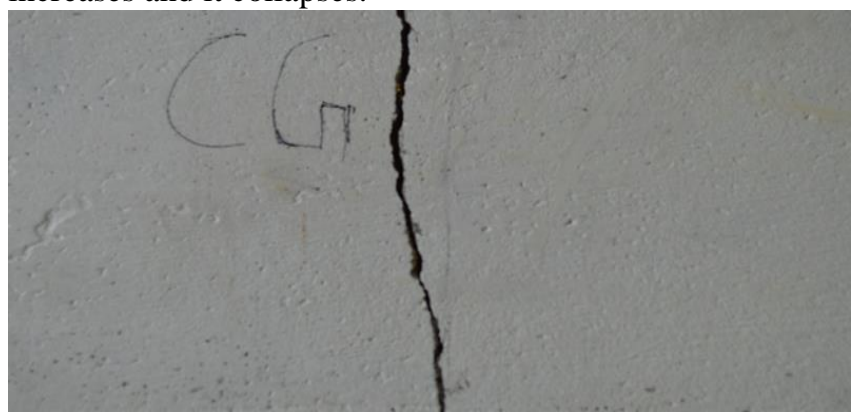

Fig.16 Crack pattern of single layer galvanized panel

Panels which are subjected to Half-cell potential tests are also tested for flexural strength test in order to find out the difference in flexural behavior. It can be seen that the $2 \%$ inhibited panel offers maximum ultimate load and maximum deflection compared to the $1 \%$ inhibited panel as well as the control panel. Table-IX shows the ultimate load and maximum deflection of single layer galvanized panel which is subjected to half-cell potential tests and flexural test.

Table-IX: Observation of ultimate load and deflection

\begin{tabular}{|c|c|c|c|c|}
\hline Sl. No & $\begin{array}{c}\text { Specimen } \\
\text { Type }\end{array}$ & Description & $\begin{array}{c}\text { Ultimate } \\
\text { Load (Kg) }\end{array}$ & $\begin{array}{c}\text { Maximum } \\
\text { deflection } \\
\text { (mm) }\end{array}$ \\
\hline 1. & CGH & $\begin{array}{c}\text { Control } \\
\text { Galvanized } \\
\text { Single Layer }\end{array}$ & 608 & 10 \\
\hline 2. & $1 \% \mathrm{IGH}$ & $\begin{array}{c}1 \% \text { Inhibited } \\
\text { Galvanized } \\
\text { Single Layer }\end{array}$ & 704 & 12 \\
\hline 3. & $2 \% \mathrm{IGH}$ & $\begin{array}{c}2 \% \text { Inhibited } \\
\text { Galvanized } \\
\text { Single Layer }\end{array}$ & 720 & 12 \\
\hline
\end{tabular}

"Fig.19" shows the load deflection behavior of the galvanized wire mesh panel during flexural test which was subjected to Half-cell potential test. It is clearly evident that the maximum deflection is comparatively low when compared to the panel which is not subjected to the half-cell potential test. The ultimate load carrying capacity of the $2 \%$ inhibited panel $(720 \mathrm{~kg})$ is higher than the $1 \%$ inhibited panel $(704 \mathrm{~kg})$ and the control panel (608kg).

"Fig.20", "Fig.21", "Fig.22" shows the crack pattern of the galvanized wire mesh panels with different percentage of corrosion inhibitor. It is clearly evident that crack pattern are similar to that of the control panel but decrease in the ultimate load carrying capacity shows that the some amount of corrosion has occurred during the half-cell potential test.

From the experimental observation it is revealed that all the panels with the galvanized wire mesh failed due to the formation of shear crack at the tension zone near the mid span of the panel irrespective of the percentage of inhibitor it showed poor performance with brittle failure of the specimen soon after the formation of first crack the addition of inhibitor add some influence on the strength of the specimen.

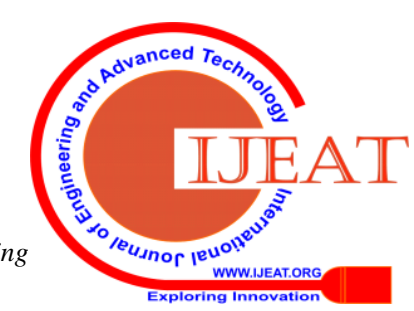




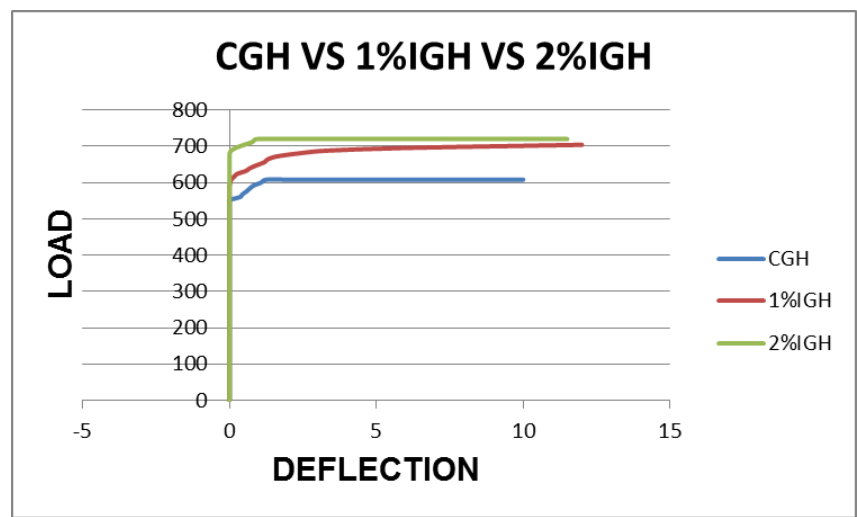

Fig.19 Load Deflection behavior of galvanized single layer galvanized Ferrocement panel

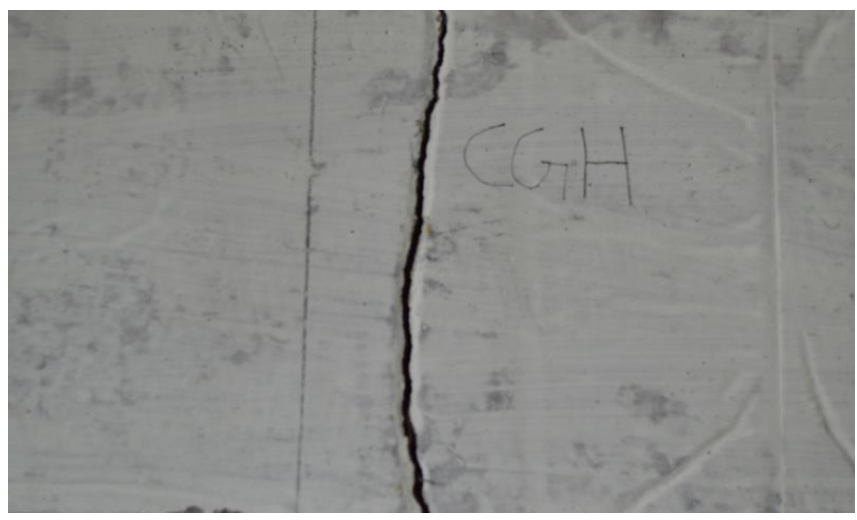

Fig.20 Crack pattern of single layer galvanized panel

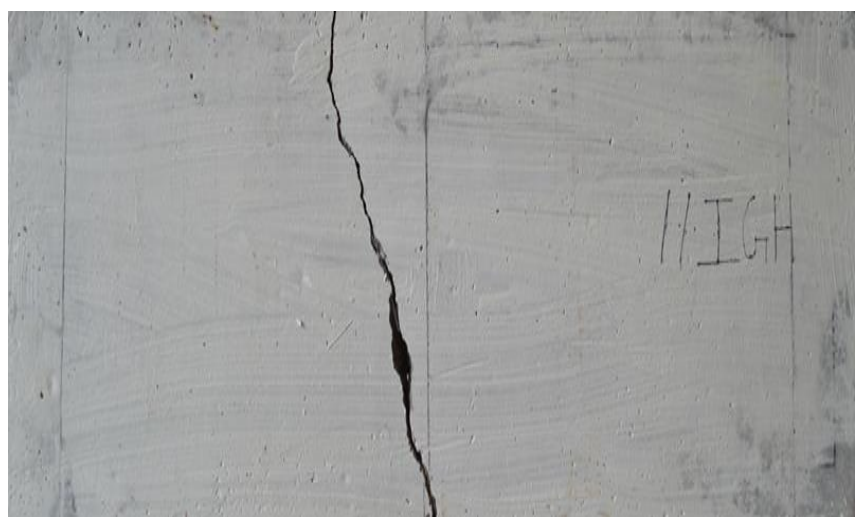

Fig.21 Crack pattern of $1 \%$ inhibited single layer galvanized panel

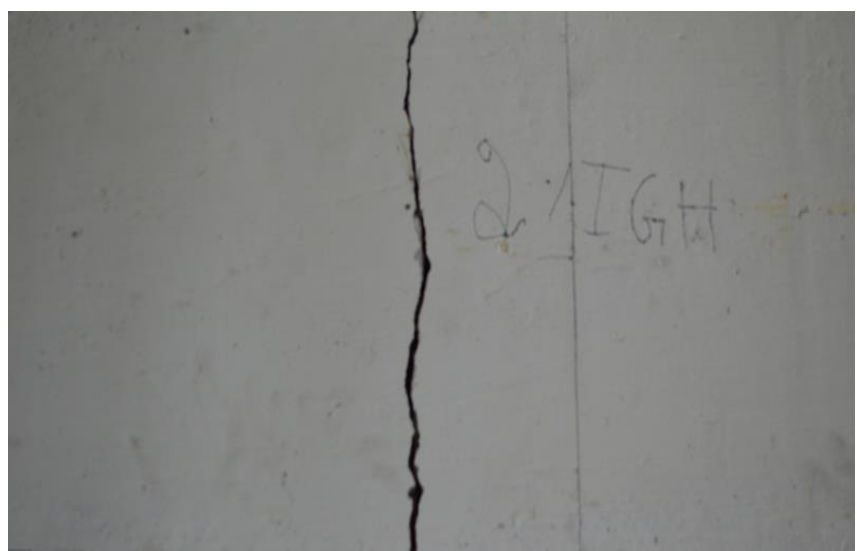

Fig.22 Crack pattern of $2 \%$ inhibited single layer galvanized panel

Table-X shows the ultimate load and maximum deflection of the single layer crimped Ferrocement panel. It is evident that the ultimate load carrying capacity of the panel $1 \%$ inhibited and $2 \%$ inhibited panel shows higher ultimate load similar to that of the control specimen.

The control which shows reduction of ultimate load carrying capacity indicates that some amount of corrosion has taken during the half-cell potential test conducted before the flexure test. It can be seen that crimped wire mesh Ferrocement panel offers more ductility as well as good flexural behavior than the galvanized Ferrocement panel. The max deflection occurred in all the crimped Ferrocement panels are all equal which shows equal ductility. The ultimate load carrying capacity of the crimped mesh varies based on the cement mortar properties.

It is evident that $1 \%$ inhibited Ferrocement panel has greater ultimate load carrying capacity $(1088 \mathrm{~kg})$ when compared to the $2 \%$ inhibited panel $(1040 \mathrm{~kg})$ and the control panel $(1008 \mathrm{~kg})$. Table $\mathrm{X}$ shows the ultimate load and maximum deflection of single layer crimped Ferrocement panel.

Table-X: Observation of ultimate load and deflection

\begin{tabular}{|c|c|c|c|c|}
\hline Sl. No & $\begin{array}{c}\text { Specimen } \\
\text { Type }\end{array}$ & Description & $\begin{array}{c}\text { Ultimate } \\
\text { Load (Kg) }\end{array}$ & $\begin{array}{c}\text { Maximum } \\
\text { deflection } \\
\text { (mm) }\end{array}$ \\
\hline 1. & CC & $\begin{array}{c}\text { Control } \\
\text { Crimped Single } \\
\text { Layer }\end{array}$ & 1008 & 24 \\
\hline 2. & $1 \%$ IC & $\begin{array}{c}1 \% \text { Inhibited } \\
\text { Crimped Single } \\
\text { Layer }\end{array}$ & 1088 & 24 \\
\hline 3. & $2 \%$ IC & $\begin{array}{c}2 \% \text { Inhibited } \\
\text { Crimped Single } \\
\text { Layer }\end{array}$ & 1040 & 24 \\
\hline
\end{tabular}

"Fig.23" Shows the load deflection behavior of crimped single layer Ferrocement panel. It can be seen that the deflection increases gradually by gradual increase in the load.

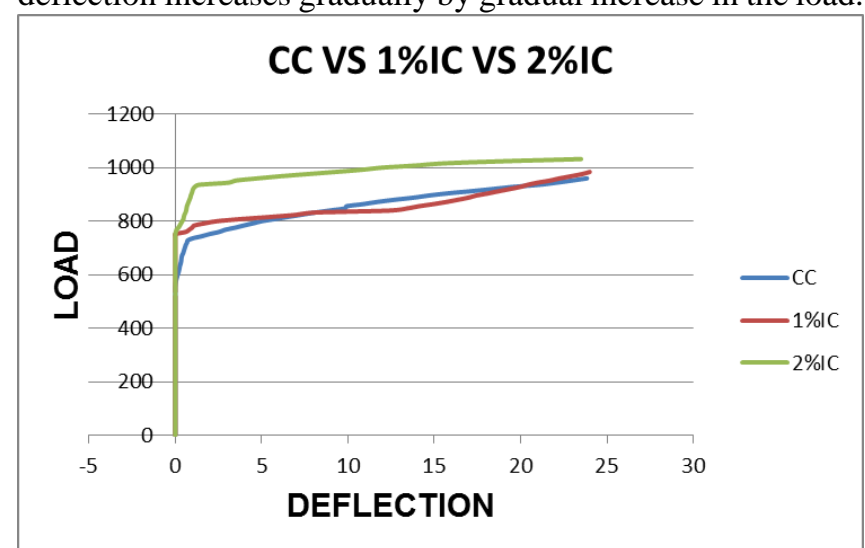

Fig.23 Load Deflection behavior of galvanized single layer crimped Ferrocement panel

"Fig.24", "Fig.25", "Fig.26" shows the crack pattern of the crimped wire mesh panels with different percentage of corrosion inhibitor. It can be seen that the no of crack propagates along the length of the panel along with deflection but there is no appreciable increase in the crack width when compared to the galvanized wire mesh panel.

\section{Published By:}

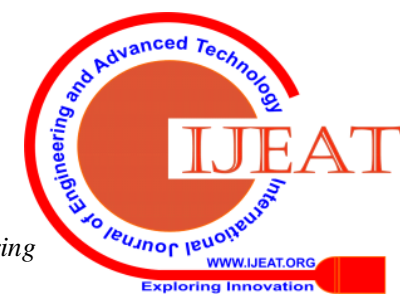




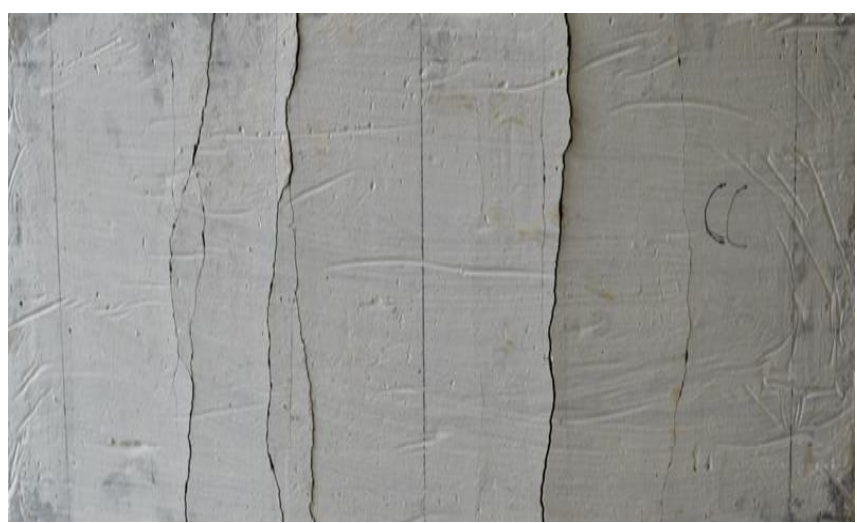

Fig. 24 Crack pattern of single layer crimped panel

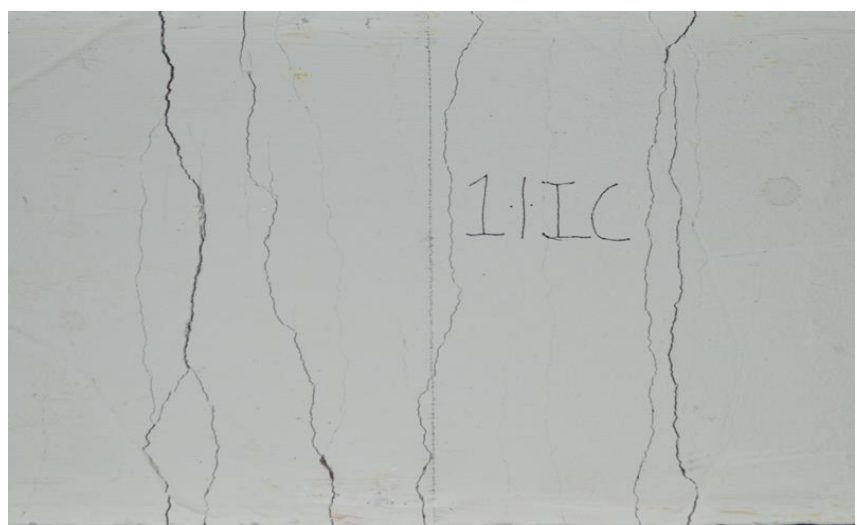

Fig. 25 Crack pattern of $1 \%$ inhibited single layer crimped panel

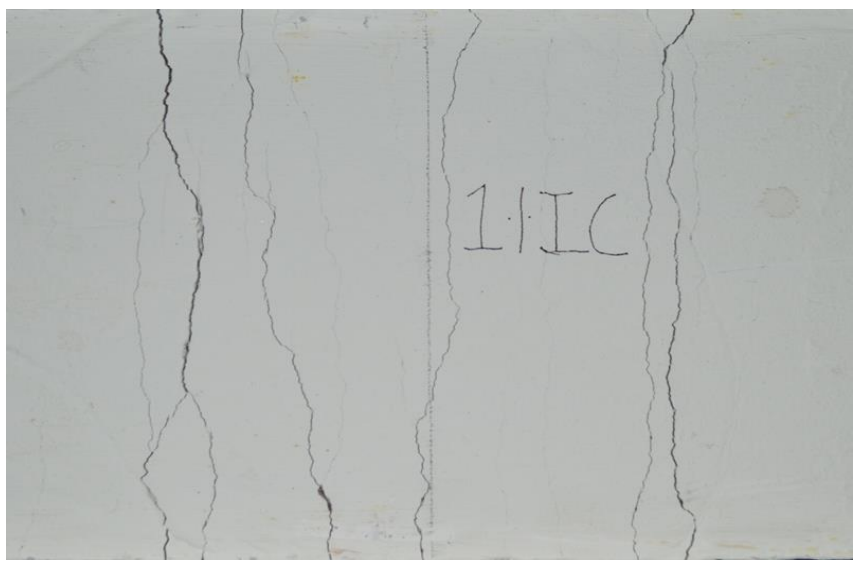

Fig. 26 Crack pattern of $2 \%$ inhibited single layer crimped panel

Table-XI shows the ultimate load and maximum deflection of crimped single layer Ferrocement panel which is subjected to half-cell potential and test and flexural test. "Fig.27" shows load deflection behavior of single layer crimped Ferrocement panel. It can be seen that the behavior is similar to that of the control panel in which there is a change only in the ultimate load carrying capacity but whereas deflection is similar.

Table-XI: Observation of ultimate load and deflection

\begin{tabular}{|c|c|c|c|c|}
\hline $\begin{array}{c}\text { Sl. } \\
\text { No }\end{array}$ & $\begin{array}{c}\text { Specimen } \\
\text { Type }\end{array}$ & Description & $\begin{array}{c}\text { Ultimate } \\
\text { Load } \\
\text { (Kg) }\end{array}$ & $\begin{array}{c}\text { Maximum } \\
\text { deflection } \\
\text { (mm) }\end{array}$ \\
\hline 1. & CC & $\begin{array}{c}\text { Control Crimped } \\
\text { Single Layer }\end{array}$ & 960 & 24 \\
\hline
\end{tabular}

\begin{tabular}{|c|c|c|c|c|}
\hline 2. & $1 \% \mathrm{IC}$ & $\begin{array}{c}1 \% \text { Inhibited Crimped } \\
\text { Single Layer }\end{array}$ & 1072 & 24 \\
\hline 3. & $2 \% \mathrm{IC}$ & $\begin{array}{c}2 \% \text { Inhibited Crimped } \\
\text { Single Layer }\end{array}$ & 1040 & 24 \\
\hline
\end{tabular}

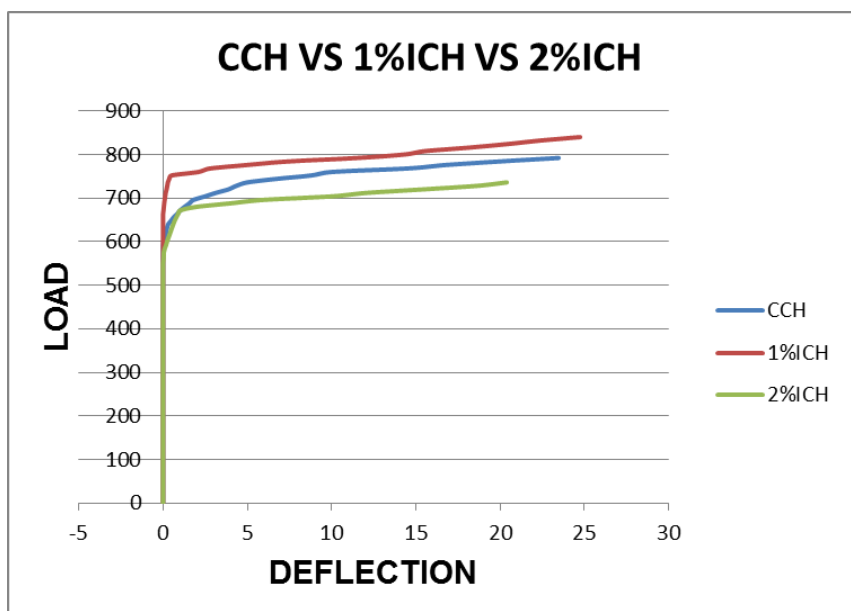

Fig. 27 Load Deflection behavior of single layer Crimped Ferrocement panel

"Fig.28", "Fig.29", "Fig.30" shows the crack pattern of respective panel.

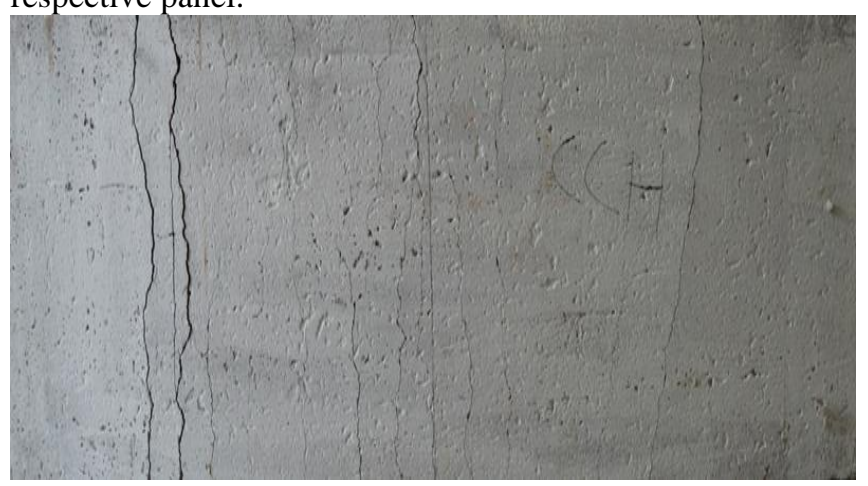

Fig. 28 Crack pattern of single layer crimped panel

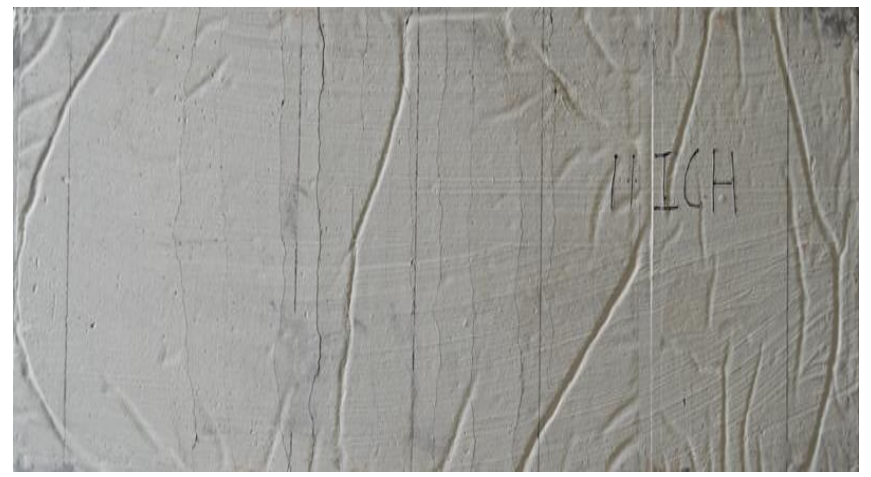

Fig. 29 Crack pattern of $1 \%$ inhibited single layer crimped panel

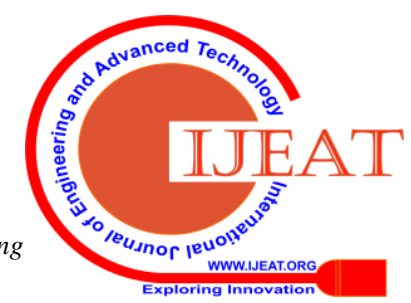




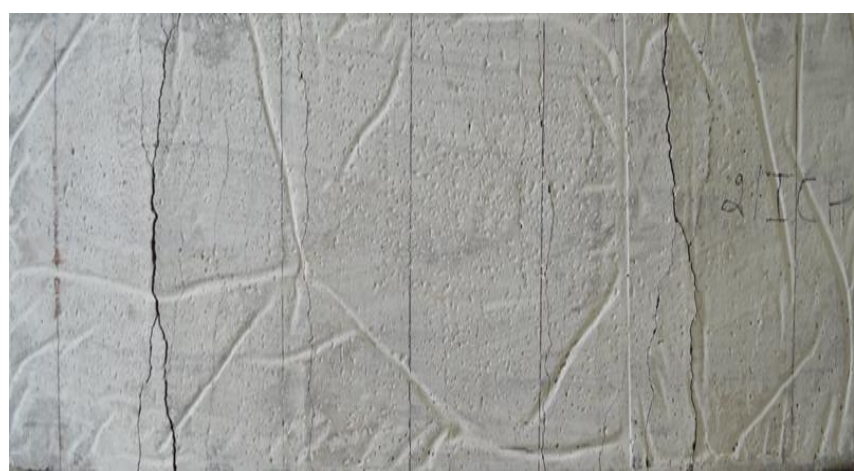

Fig. 30 Crack pattern of $2 \%$ inhibited single layer crimped panel

The panels casted with crimped wire mesh exhibited better performance with the failure due to flexural crack distributed along the effective span at the tension zone of the panel. The addition of corrosion inhibitor exhibits better flexural behavior by increased ultimate load carrying capacity. The panel which is subjected to half-cell potential test and flexural test showed exactly the same behavior but only difference is the ultimate load carrying capacity. The control specimen showed reduction in the ultimate load carrying capacity. Thus it can be concluded that $1 \%$ inhibited Ferrocement panel offers good strength and durable performance.

\section{CONCLUSION}

Totally 24 panels were cast to obtain the strength and durability performance of Ferrocement panels with addition of corrosion inhibitor. Based on the test results obtained from the strength and durability tests, the following conclusions are drawn:

- Inhibitor admixed mortar offers marginally improved resistance against water absorption irrespective of tested dosage levels as compared to control mortar.

- There is an appreciable reduction in current development in the order of $18 \%$ for inhibitor admixed mortar as compared to control mortar, which is an indication of improved resistance against chloride penetration.

- Half-cell potential readings on galvanized ferrocement panels should not be interpreted for corrosion probability as per ASTM C876.

- Ferrocement panels with crimped wire mesh and inhibitor modification offered low corrosion risk at the end of test period as per ASTM C876.

- There is an improvement in ultimate load carrying capacity for galvanized mesh ferrocement panels of the order of $11-16 \%$ upon inhibitor modification in mortar. Similar ultimate load carrying capacity for crimped wire mesh ferrocement panels for control and inhibitor modified mortar. Ductile behavior associated with multiple crack formation before failure is observed for all tested panels. It can be concluded that crimped wire mesh ferrocement panels offered appreciable stiffness, load carrying capacity and ductility as compared to galvanized mesh ferrocement panel. Inhibitor incorporation appreciably improves the durability performance of ferro cement panels.

\section{REFERENCES}

1. M.S Mathews, J. Sudhakar, P. Jayashree (1993) "Durability studies on ferrocement" Journal of Ferrocement, vol 23, No.1.

2. R.U.Halwatura, M.T.R. Jayasinghe (2008), "Thermal performance of insulated roof slabs in tropical climates", Energy and Buildings, vol 40, pp 1153-1160.

3. M.A Saleem and M. Ashraf(2008),'Low Cost Earthquake Resistant Ferrocement Small House", Pak. J. Engg. \& Appl.Sci.Vol. 2.

4. Wail N. Al-Rifaie and Muyasser M. Joma'ah (2010)," Structural Behaviour of Ferrocement System for Roofing", Diyala Journal of Engineering Sciences, pp. 237-248.

5. M. A. Mansur, Mohamed Maalej, and Mohammad Ismail (2008)," Study on Corrosion Durability of Ferrocement", ACI Materials Journal Title no. 105-M04.

6. P.B. Sakthivel and A. Jagannathan(2012)," Study on Flexural Behaviour of Ferrocement Slabs Reinforced with PVC-coated Weld Mesh", International Journal of Engineering Research and Development, ISSN: 2278-067X, Volume 1, Issue 12, PP. 50-57.

7. BIS - 4031 (Part 4) - 1988, "Determination of Consistency of Standard Cement Paste",

8. BIS-4031 (Part 5)-1988, "Determination of Initial and Final Setting Time".

9. BIS - 516 - 1959, 'Method of tests for strength of concrete'

10. ASTM C-1202, 'Standard Test Method for Electrical Indication of Concrete's Ability to Resist Chloride Ion Penetration'.

11. ASTM C-876 - 09, ' Standard Test Method for Corrosion Potentials of Uncoated Reinforcing Steel in Concrete'

12. ASTM C642-06,"Standard Test Method for Density, Absorption, and Voids in Hardened Concrete"

\section{AUTHORS PROFILE}

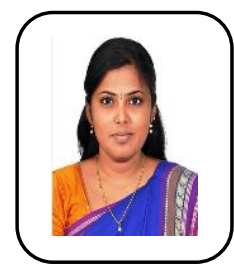

Mrs. S.Saranya, (B.E (Civil),, M.Tech (Structural Engineering)), Assistant Professor in the Department of Civil Engineering, R.M.K.Engineering College, Kavaraipettai, Tamilnadu, India. She has nearly 5 publications in various National and International Journals. She is a life time Member in the Indian Society for Technical Education (ISTE).

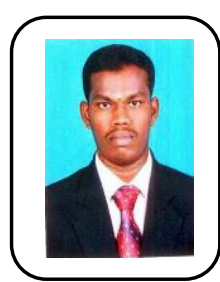

Mr.S.P.Kanniyappan, (B.E. (Civil), M.E (Construction Engineering Management), Assistant Professor in the Department of Civil Engineering R.M.K.Engineering College, Kavaraipettai, Tamilnadu, India. He has nearly 25 publications in various National, International Journals \& Conferences. He is a life time Member in the Indian Society for Technical Education, International Association of Engineers and Institute of Engineers.

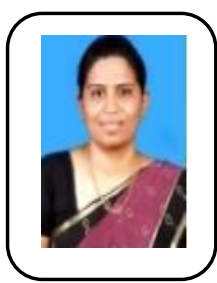

Mrs. A.Faizuneesa, (B.E (Civil)., M.E (Environmenta Engineering)), Assistant Professor in the Department of Civil Engineering, R.M.K.Engineering College, Kavaraipettai, Tamilnadu, India. She has nearly 5 publications in various National and International Journals. She is a life time Member in the Indian Society for Technical Education (ISTE).

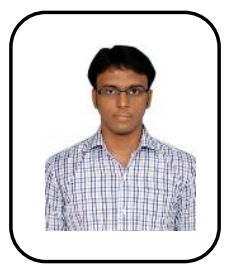

Mr.R.G.Dhilip Kumar, (B.E (Civil)., M.E (Structura Engineering)), Assistant Professor in the Department of Civil Engineering, R.M.K.Engineering College, Kavaraipettai, Tamilnadu, India. He has nearly 5 publications in various Journals and Conferences. He is a life time Member in the Indian Society for Technical Education (ISTE) 